\title{
10. CENOZOIC RADIOLARIANS FROM THE CENTRAL PACIFIC, DSDP LEG 33'
}

\author{
David A. Johnson, Woods Hole Oceanographic Institution, Woods Hole, Massachusetts
}

\section{INTRODUCTION}

Radiolarians were identified in each of the five sites drilled on Leg 33. The locations of these sites are listed in Table 1.

Of these five sites, only one (Hole 317B) recovered a substantial thickness of radiolarian-bearing sediment within a continuously cored interval. The remaining sites were spot-cored within the Cenozoic portion of the section. Pre-Eocene sediments at all sites are barren of radiolarians, except for small quantities of calcified radiolarian tests within certain intervals in Holes $315 \mathrm{~A}$ and 317A.

\section{SCOPE OF INVESTIGATION AND PRESENTATION OF RESULTS}

After preliminary shipboard analysis of all corecatcher samples, each core within which radiolarians had been identified was sampled at intervals of one or more samples per section $(1$ section $=150 \mathrm{~cm})$. In the intervals where core-catcher examination revealed no radiolarians, only one or two additional samples per core were taken $(1$ core $\cong 9.5 \mathrm{~m})$. Slides of coarse fraction preparations ( $>62 \mu \mathrm{m}$ ) were prepared according to standard techniques described by Riedel (1957) and Riedel and Sanfilippo (in press).

Preparation of samples from the pre-Eocene intervals of the cores yielded no radiolarians. Coarse fractions of many of these samples were also prepared without the final step of HCL addition, thereby leaving all material $>62 \mu \mathrm{m}$ including the calcareous component. In some of these sample preparations, small percentages of calcified radiolarian tests (principally Dictyomitra spp.) were observed within the foraminiferal assemblages. Because of the extensive recrystallization, however, these radiolarian specimens could be identified only at the tution. generic level using conventional examination procedures. Consequently, the scattered occurrences of Cretaceous radiolarians at Leg 33 sites will not be considered in this report. Scanning electron microscopy would probably be required to identify these species and assign a stratigraphic age using the Cretaceous radiolarian zonations which have recently been developed (Moore, 1973; Foreman, 1973a, b; Riedel and Sanfilippo, 1974).

The Cenozoic intervals of the Leg 33 sites generally contain common and well-preserved radiolarian assemblages, except for the disappearance of radiolarians below the depths where Eocene cherts first appear, a difficulty which has been encountered at many previous sites. The principal objective of this study was to examine the Cenozoic radiolarian-bearing sediments at Leg 33 sites and identify the occurrences of all radiolarian taxa previously known to be stratigraphically useful. Because of extensive drilling in the central Pacific prior to Leg 33 , a relatively precise radiolarian zonation for the region had been established previously (Riedel and Sanfilippo, 1971; Dinkelman, 1973), and no attempt was made to modify or refine this zonation on the basis of the limited additional material available in Leg 33 cores. The occurrences of Cenozoic radiolarians are discussed and summarized in tabular form in the following section. In the discussion which follows and in the tabulations, the names of most of the radiolarian taxa are abbreviated. Their full and correct form is given in the List of Species at the end of this report.

\section{CENOZOIC RADIOLARIAN ZONATION}

Investigations of sediments cored on earlier legs of the Deep Sea Drilling Project have yielded a radiolarian zonation which covers most of the Cenozoic. This zonation scheme has been followed in this report. The zonal boundaries and ranges of taxa for the upper Paleocene to lower Eocene are described by Sanfilippo and Riedel (1973) and Foreman (1973a); the zonation for the middle to upper Eocene is that of Riedel and Sanfilippo (1970), as modified by Foreman (1973b); the zonation

TABLE 1

Site Locations

\begin{tabular}{ccclrr}
\hline Site & Latitude & Longitude & \multicolumn{1}{c}{ Location } & $\begin{array}{c}\text { Water } \\
\text { Depth } \\
(\mathrm{m})\end{array}$ & $\begin{array}{c}\text { Drilling } \\
\text { Pene- } \\
\text { tration } \\
(\mathrm{m})\end{array}$ \\
\hline 314 & $15^{\circ} 54.76^{\prime} \mathrm{N}$ & $168^{\circ} 28.07^{\prime} \mathrm{W}$ & Johnston Island Trough & 5225 & 45 \\
315 & $04^{\circ} 10.26^{\prime} \mathrm{N}$ & $158^{\circ} 31.54^{\prime} \mathrm{W}$ & Fanning Island Fan & 4164 & 1034 \\
316 & $00^{\circ} 05.44^{\prime} \mathrm{N}$ & $157^{\circ} 07.71^{\prime} \mathrm{W}$ & Line Islands, Southern End & 4464 & 837 \\
317 & $11^{\circ} 00.09^{\prime} \mathrm{S}$ & $162^{\circ} 15.78^{\prime} \mathrm{W}$ & Manihiki Plateau & 2622 & 943 \\
318 & $14^{\circ} 49.63^{\prime} \mathrm{S}$ & $148^{\circ} 51.51^{\prime} \mathrm{W}$ & Tuamotu Islands & 2659 & 745 \\
\hline
\end{tabular}


used for the Oligocene through Pliocene is that of Riedel and Sanfilippo (1971). The Quaternary zonation is that of Nigrini (1971).

The Cenozoic radiolarian zones used in this study, along with the definitions of the zonal boundaries, are listed below in order from oldest to youngest, beginning with the middle Eocene:

\section{Eocene (Middle to Late)}

Theocampe mongolfieri Zone

Base: First evolutionary appearance of Theocampe mongolfieri from Theocampe amphora.

Thyrsocyrtis triacantha Zone

Base: First evolutionary appearance of Thyrsocyrtis triacantha from Thyrsocyrtis hirsuta tensa.

Podocyrtis ampla Zone

Base: First evolutionary appearance of Podocyrtis ampla from Podocyrtis phyxis.

Podocyrtis mitra Zone

Base: First evolutionary appearance of Podocyrtis mitra from Podocyrtis sinuosa.

Podocyrtis chalara Zone

Base: First evolutionary appearance of Podocyrtis chalara from Podocyrtis mitra.

Podocyrtis goetheana Zone

Base: First evolutionary appearance of Podocyrtis goetheana from Podocyrtis chalara.

Thyrsocyrtis bromia Zone

Base: First evolutionary appearance of Thyrsocyrtis bromia.

\section{Oligocene}

\section{Theocyrtis tuberosa Zone}

Base: First evolutionary appearance of Lithocyclia angustum from Lithocyclia aristotelis.

Dorcadospyris ateuchus Zone

Base: First evolutionary appearance of Dorcadospyris ateuchus from Dorcadospyris triceros.

Lychnocanoma elongata Zone (synonymous with Lychnocanium bipes Zone)

Base: First morphotypic appearance of Lychnocanoma elongata.

\section{Miocene}

\section{Calocycletta virginis Zone}

Base: First evolutionary appearance of Calocycletta virginis from Calocycletta robusta.

Calocycletta costata Zone

Base: First evolutionary appearance of Calocycletta costata from Calocycletta virginis.

Dorcadospyris alata Zone

Base: First evolutionary appearance of Dorcadospyris alata.

Cannartus (?) petterssoni Zone

Base: First morphotypic appearance of Cannartus (?) petterssoni.

Ommatartus antepenultimus Zone

Base: First evolutionary appearance of Ommatartus antepenultimus from Cannartus laticonus.

Ommatartus penultimus Zone

Base: First evolutionary appearance of Ommatartus penultimus from Ommatartus antepenultimus.
Stichocorys peregrina Zone

Base: First evolutionary appearance of Stichocorys peregrina from Stichocorys delmontensis.

\section{Pliocene}

Spongaster pentas Zone

Base: First morphotypic appearance of Pterocanium prismatium.

Pterocanium prismatium Zone

Base: Last occurrence of Stichocorys peregrina.

\section{Quaternary}

Anthocyrtidium angulare Zone (=Zone 4)

Base: Last occurrence of Pterocanium prismatium.

Amphirhopalum ypsilon Zone (=Zone 3 )

Base: Last occurrence of Anthocyrtidium angulare.

Collosphaera tuberosa Zone (=Zone 2)

Base: First morphotypic appearance of Collosphaera tuberosa.

Buccinosphaera invaginata Zone (=Zone 1)

Base: Evolutionary transition from Collosphaera sp. A to Buccinosphaera invaginata (see Knoll and Johnson, 1975).

\section{RADIOLARIANS AT EACH SITE}

In this section, the information on occurrences of Cenozoic radiolarians is tabulated in Tables 2 and 3 for those sites at which significant sequences of radiolarianbearing sediments were cored (Sites 315 and 317); radiolarian occurrences at the remaining sites $(314,316$, 318) are described in the text.

The abundance of radiolarians in each sample is indicated in the tables as "very abundant" (A), "common" (C), "few" (F), "rare" (R), or "very rare" (+). Preservation of the specimens is indicated as "excellent" (E), "good" (G), "moderate" (M), or "poor" (P).

In the columns showing occurrences of individual species, the same relative abundance terms are used to indicate the proportion that a given species constitutes of the total radiolarian assemblage. A dash (-) indicates that the species was searched for but was not found. Occurrences believed to result from the reworking of older material into younger sediments, or from downward caving resulting in introduction of younger forms into older assemblages, are marked with an asterisk (*).

\section{Site 314}

A highly diversified assemblage of moderately to wellpreserved radiolarians of Eocene age was observed in several small samples of material recovered at Site 314 . Small volumes (several cc) of sediment were examined from the catcher of Core 1 (depth $=9.5 \mathrm{~m}$ ), from the outer surface of the drill collars at 10.5 meters and 12 meters above the drill bit (depth $=0$ to $34 \mathrm{~m}$ ), and from the catcher of Core 3 (depth $=45 \mathrm{~m}$ ).

In Sample 314-1, CC, poorly preserved fragments of Eocene radiolarians were observed, including Thyrsocyrtis triacantha, T. tetracantha, and Theocorys sp. cf. $T$. anaclasta. The sediment samples from the drill collars contain numerous radiolarian species of early Eocene to late Eocene age. Early Eocene specimens present include Clathrocycloma sp. aff. C. capitaneum, Dorcadospyris 
confluens, Calocycloma castum, Dendrospyris fragoides, and Dictyospyris gigas. Species characteristic of the middle Eocene include Podocyrtis diamesa, Thyrsocyrtis triacantha, and Rhopalocanium ornatum. Late Eocene species include Lithapium mitra, Thyrsocyrtis tetracantha, and Podocyrtis chalara. The stratigraphic ranges of these species are nonoverlapping. Moreover, scattered specimens of Polysolenia sp. and Pterocanium sp. were observed, suggesting a late Cenozoic age. The above evidence suggests that much of the material present in these samples may be reworked, indicative of substantial erosion of Eocene sediments at some time during the late Cenozoic. Alternatively, since the drill collar samples could represent virtually any interval between the sea floor and a subbottom depth of 34 meters, the mixed nature of the radiolarian assemblages may be an artifact of the drilling process.

In the clays and claystones recovered in the catcher of core $3($ depth $=45 \mathrm{~m})$, moderately preserved specimens of Eocene radiolarians were identified, including: Theocampe mongolfieri, Thyrsocyrtis triacantha, Thyrsocyrtis rhizodon, Podocyrtis papalis, Calocyclas hispida, Lithomitra docilis, Podocyrtis goetheana, Eusyringium fistuligerum, and Podocyrtis sinuosa.

The presence of these species is consistent with a middle to late Eocene age for the deepest sample recovered from Site 314.

\section{Site 315}

Radiolarians are common to abundant and well preserved in the Quaternary through upper Oligocene sediments recovered at Holes 315 and $315 \mathrm{~A}$ (Cores 3151 through 315A-9; depth 0 to $705 \mathrm{~m}$ ). Radiolarians exhibit decreasing abundance and poorer preservation within the lower Oligocene and upper Eocene sediments (Core 315A-10) and are absent in all samples examined below Core 10 (depth $=741 \mathrm{~m})$, except for small percentages of calcified radiolarian tests in samples from 315A22-4 and 315A-25, CC of Campanian age.

The following radiolarian zonal boundaries can be recognized within the radiolarian-bearing sediments at Site 315 (see Table 2).

The base of the Collosphaera tuberosa Zone lies between 1 and 2 meters (between 315-1-1 and 315-1-2). The base of the Amphiropalum ypsilon Zone lies between 9 and 56 meters (between 315-1, CC and 315-4-1). The Anthocyrtidium angulare Zone and Pterocanium prismatium Zone may occur in the unsampled interval between 9 and 56 meters (between Samples 315-1, CC and 315-4-1), or may be missing from this site. The base of the Spongaster pentas Zone occurs between 65 and 75 meters (between Samples 315-4, CC and 315A-1-1). The base of the Stichocorys peregrina Zone lies between 85 and 123 meters (between Samples 315A-1, CC and 315A-2-1). The Ommatartus penultimus Zone was not sampled. The base of the Ommatartus antepenultimus Zone occurs at 151 meters (between Samples 315A-36 and 314A-3, CC). The base of the Cannartus petterssoni Zone occurs between 151 and 256 meters (between Samples 315A-3, CC and 315A-4-1). The base of the Dorcadospyris alata Zone occurs at 371 meters (between Samples 315A-5-1 and 315A-5-2). The base of the
Calocycletta costata Zone occurs at 468 meters (between Samples 315A-6-3 and 315A-6, CC). The base of the Calocycletta virginis Zone occurs between 522 and 588 meters (between Samples 315A-7, CC and 315A-8-1). The base of the Lychnocanoma elongata Zone occurs between 598 and 702 meters (between Samples 315A-8, $\mathrm{CC}$ and 315A-9-1). The base of the Dorcadospyris ateuchus Zone occurs between 712 and 730 meters (between Samples 315A-9, CC and 315A-10-1). The Theocyrtis tuberosa Zone may occur in the uncored interval between 712 and 730 meters, or in the upper sections of Core 315A-10 (730 to $734 \mathrm{~m}$ ). The Thyrsocyrtis bromia Zone is represented in samples from the lower sections of Core 315A-10 (734 to $740 \mathrm{~m}$ ). Samples from below 740 meters (Sample 315A-10, CC) were devoid of identifiable radiolarians.

\section{Site 316}

At Site 316 five spot cores were taken in the upper 457 meters of sediment, representing the Quaternary through lower Oligocene portion of the section. Radiolarians are common and well preserved in all samples examined from this interval. Cherts of middle Eocene age were encountered near the base of Core 3165 (depth $=457 \mathrm{~m})$, and below this point radiolarians were absent.

In Core 316-1 (depth $=0$ to $9.5 \mathrm{~m}$ ) radiolarian assemblages indicate a Quaternary age, but assignment of zonal names is difficult because of absence of many of the required taxa. Axoprunum angelinum is present in all samples examined from Core 1, and Pterocanium prismatium and Anthocyrtidium angulare are absent. This suggests that Core 1 may lie entirely within Nigrini's (1971) Amphirhopalum ypsilon Zone (= Zone $3)$. Rare specimens of Tertiary radiolarians occur in some assemblages examined from Core 1, indicating either erosion and redeposition of Tertiary sediments, or vertical mixing from the underlying strata.

The Ommatartus antepenultimus Zone is represented in Core 316-2 and the upper portion of Core 316-3 (between 153 and $268 \mathrm{~m}$ ). The following species were identified in samples from this interval and serve to identify the $O$. antepenultimus Zone: Stichocorys delmontensis, Phormostichoartus corona, Ommatartus antepenultimus, Artostrobium doliolum, Ommatartus hughesi, Calocycletta caepa, Stichocorys peregrina, Lithopera bacca, and Lithopera neotera.

The top portion of Core 316-3, between a depth of 267 and 269 meters, represents either an erosional unconformity or an interval of very low accumulation rates. Four consecutive radiolarian zones were sampled within this 2-meter interval: Ommatartus antepenultimus Zone (316-3-1, 72-74 cm); Cannartus petterssoni Zone (316-31, 120-122 cm); Dorcadospyris alata Zone (316-3-2, 19$21 \mathrm{~cm})$; and Calocycletta costata Zone (316-3-2, 77-79 $\mathrm{cm})$. Diagnostic species indicative of the $O$. antepenultimus Zone are listed above; those for the remaining three zones are as follows:

Cannartus petterssoni Zone: Lithopera neotera, Cannartus petterssoni, Cannartus laticonus, Stichocorys delmontensis, Phormostichoartus corona, Lithopera renzae, Artostrobium doliolum, Calocycletta caepa, Dorcadospyris alata, and Cyrtocapsella cornuta. 
TABLE 2

Radiolarians at Site $\mathbf{3 1 5}$

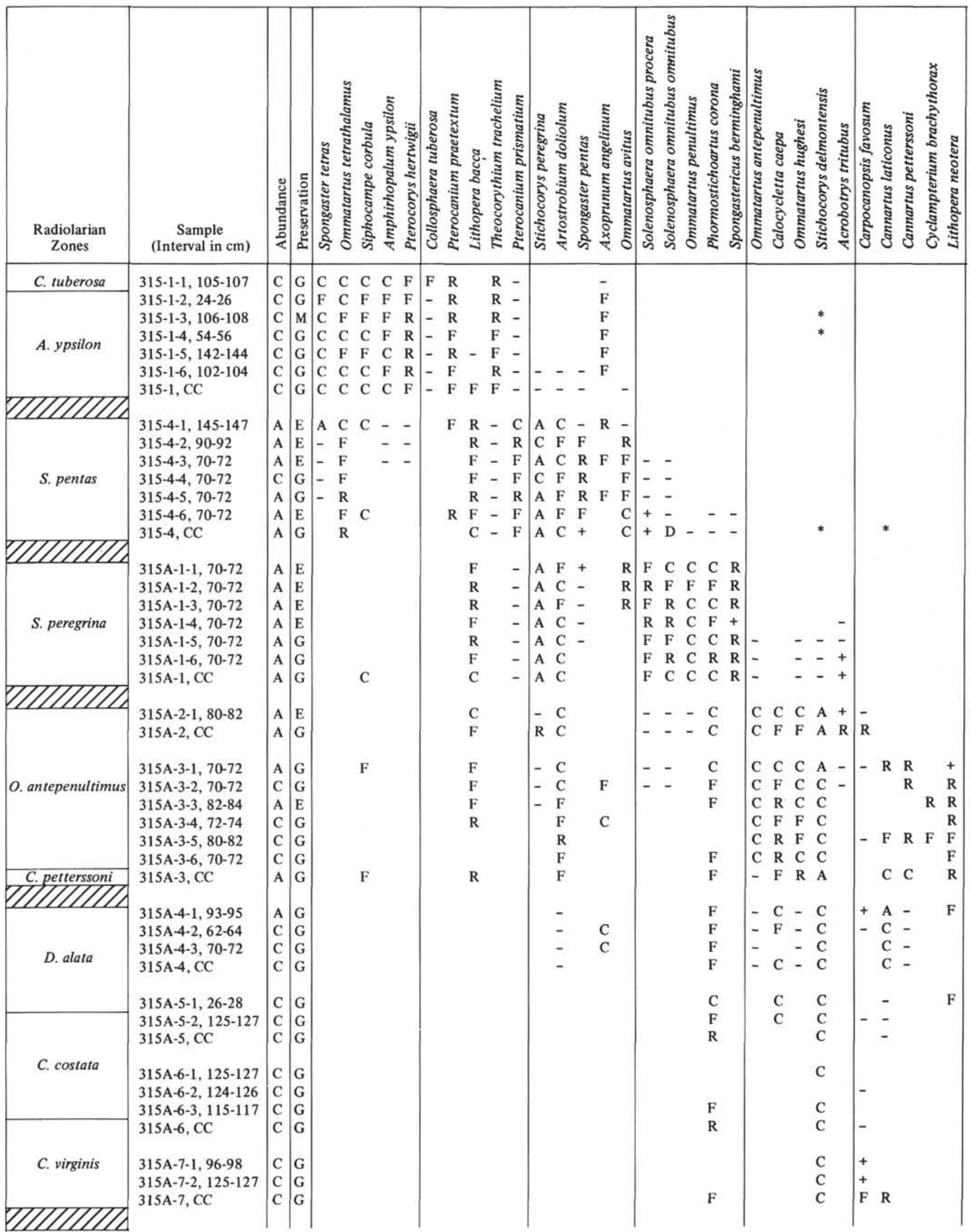


TABLE 2 - Continued

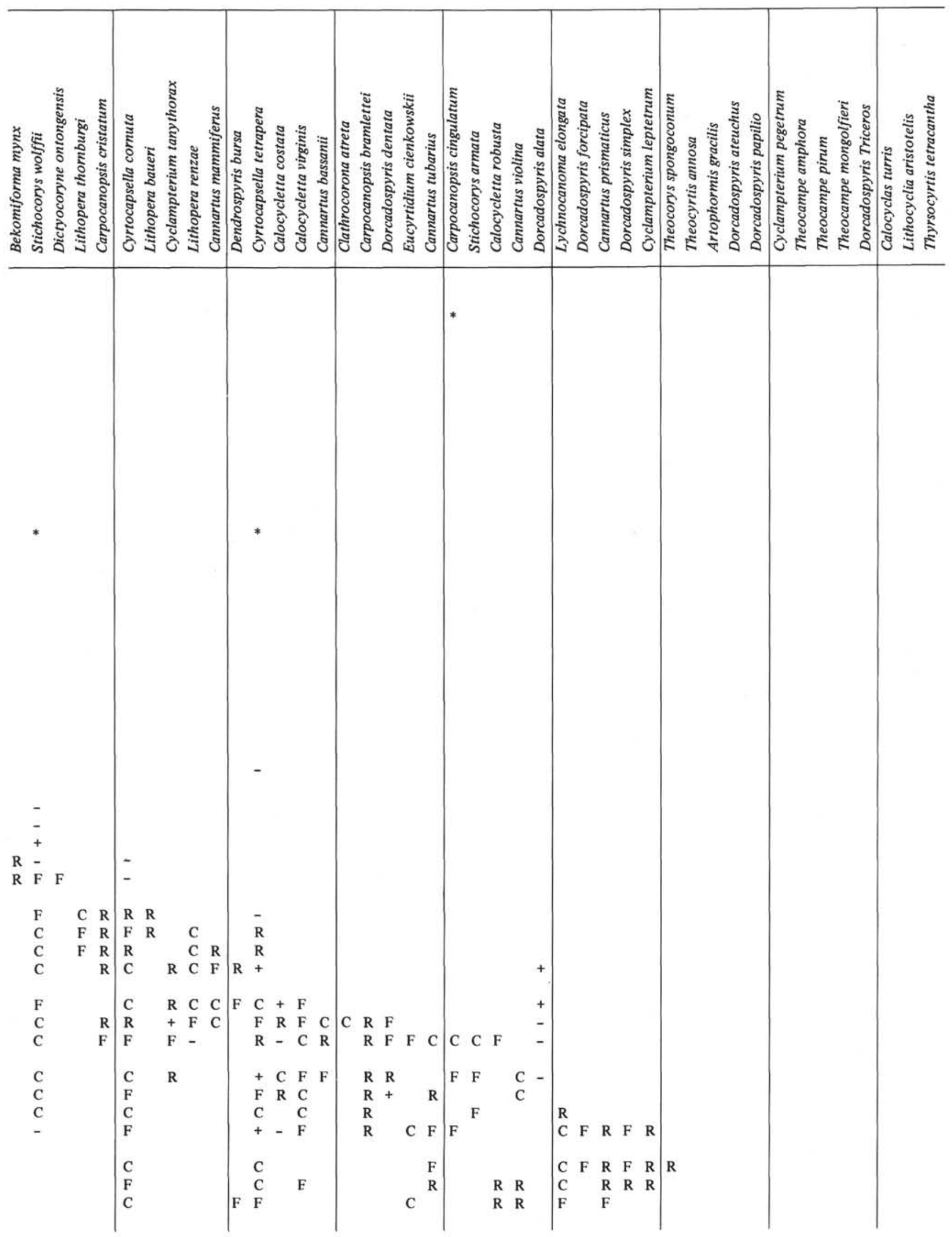


TABLE 2 - Continued

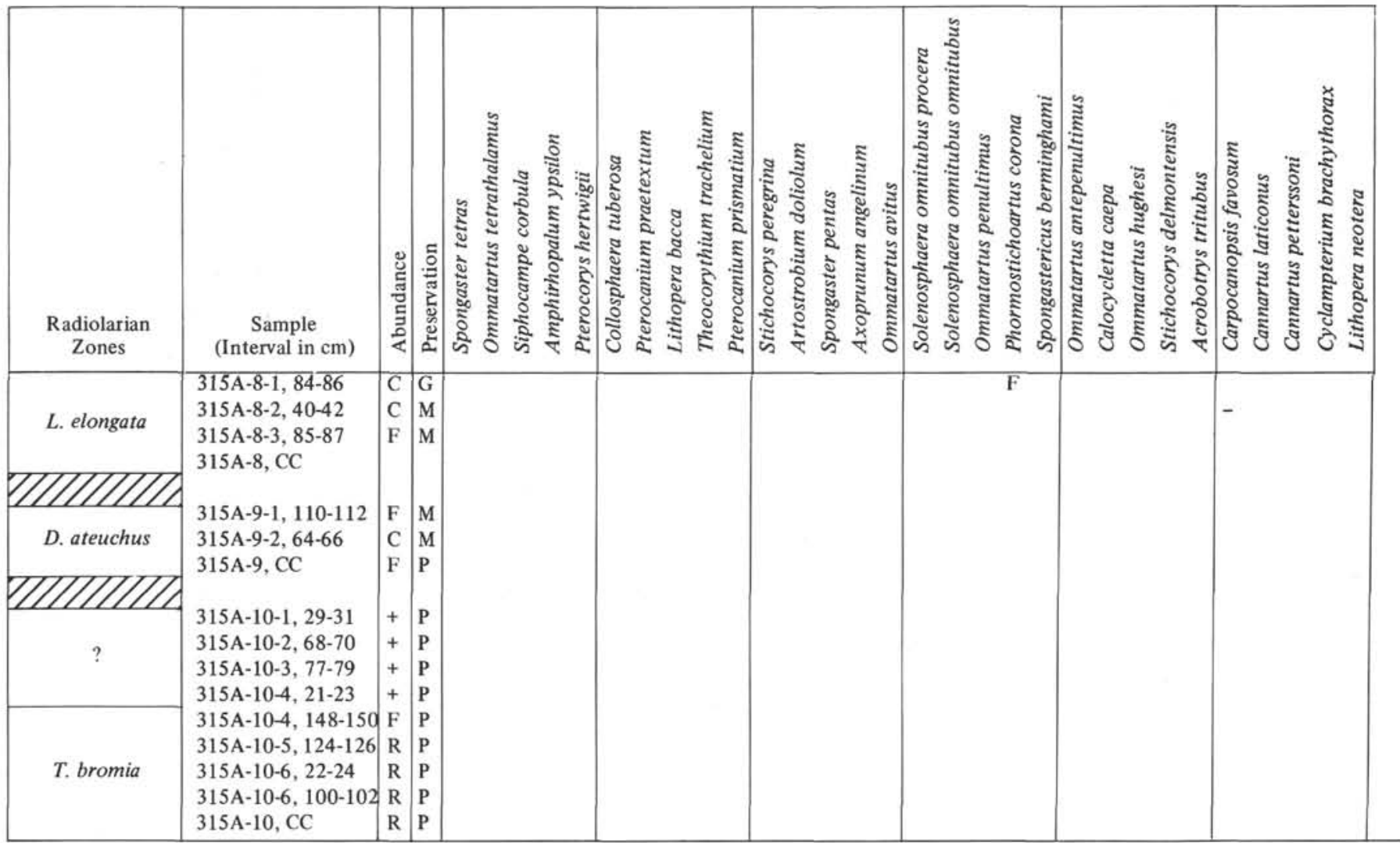

Dorcadospyris alata Zone: Cyrtocapsella cornuta, Stichocorys delmontensis, Phormostichoartus corona, Cyclampterium tanythorax, Lithopera renzae, Lithopera baueri, Calocycletta caepa, Cyrtocapsella tetrapera, Dorcadospyris alata, and Lithopera neotera.

Calocycletta costata Zone: Cyrtocapsella cornuta, Calocycletta virginis, Stichocorys armata, Stichocorys delmontensis, Lithopera renzae, Cannartus tubarius, Calocycletta costata, Calocycletta caepa, Dorcadospyris dentata, Carpocanopsis bramlettei, and Carpocanopsis cristatum.

The lower portion of Core 316-3, between 269 and 276 meters, lies within the Calocycletta costata Zone. Samples examined from this interval contain the diagnostic taxa listed above, as well as Stichocorys wolffii, Carpocanopsis cingulatum, Cyrtocapsella tetrapera, and Cannartus bassanii.

Within Core $316-4$ (depth $=390$ to $400 \mathrm{~m}$ ) there is at least one erosional unconformity. Samples from 391 to 392 meters (316-4-1, $81-83 \mathrm{~cm} ; 316-4-2,35-37 \mathrm{~cm})$ lie within the upper quarter of the Calocycletta virginis Zone, as indicated by the presence of the following taxa: Stichocorys wolffi, Cyrtocapsella cornuta, Dorcadospyris dentata, Phormostichoartus corona, Calocycletta virginis, Cannartus tubarius, Carpocanopsis bramlettei, Carpocanopsis cristatum, Dorcadospyris forcipata, and Cyrtocapsella tetrapera.

A sample from 392.5 meters $(316-4-2,83-85 \mathrm{~cm})$ lies within the Lychnocanoma elongata Zone, on the basis of a few poorly preserved specimens of $L$. elongata, Dorcadospyris ateuchus, and Theocorys spongoconum. Deeper samples in Core 316-4 (393 to $400 \mathrm{~m}$ ) lie within the Dorcadospyris ateuchus Zone, on the basis of the following diagnostic taxa: Dorcadospyris ateuchus, Theocyrtis annosa, Cannartus prismaticus, Artophormis gracilis, Cyclampterium pegetrum, Centrobotrys petrushevskayae, Lithocyclia crux, Dorcadospyris circulus, and Dorcadospyris praeforcipata.

Reworked Eocene radiolarians are common in Sample $316-4, C C$, indicating that substantial lateral and/or vertical mixing occurred at this site during the late Oligocene. Diagnostic taxa indicative of this Eocene admixture include Theocampe amphora, T. urceolus, Thyrsocyrtis triacantha, Amphicraspedum murrayanum, and Lychnocanoma babylonis.

The upper portion of Core 316-5 (depth $=447$ to 450 $\mathrm{m})$ lies within the Theocyrtis tuberosa Zone of early Oligocene age, as indicated by the following species: Theocyrtis tuberosa, Artophormis gracilis, Cyclampterium milowi, Dorcadospyris spinosa, Dorcadospyris quadripes, Cyclampterium pegetrum, Lithocyclia angustum, Dorcadospyris triceros, Theocampe urceolus, Lithocyclia crux, and Lophophaena (?) capito.

No siliceous material was observed below a depth of 450 meters (Sample 316-5-2, 116-118 cm). Any siliceous microfossils deposited at this site prior to the Oligocene have evidently been remobilized and converted to chert.

\section{Site 317}

Three holes were drilled at this site. The coring strategy involved (1) washing down to the Tertiary/Cretaceous boundary to minimize bit wear; (2) coring continuously to and into basement; (3) pulling 
TABLE 2 - Continued

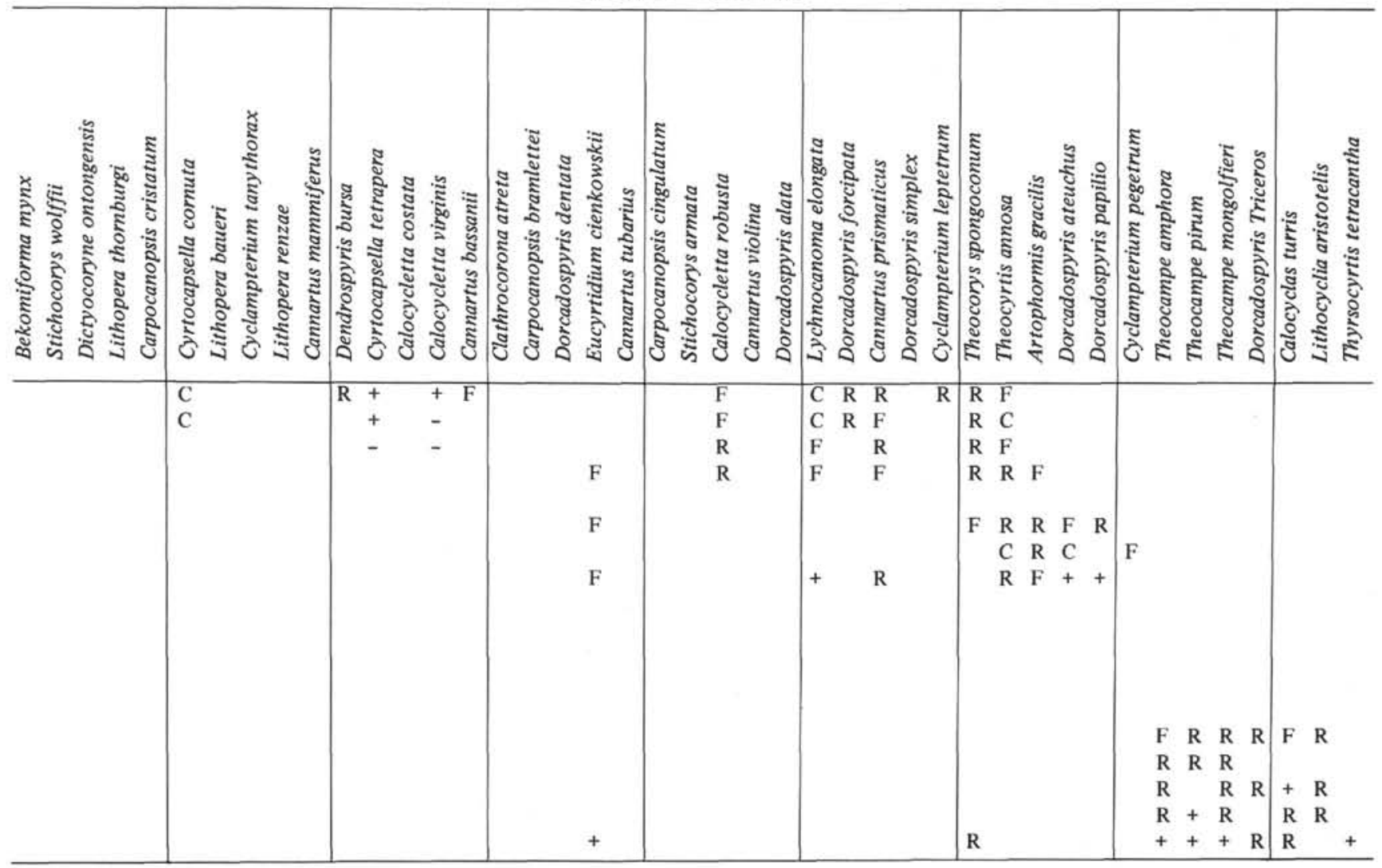

the drill string, respudding with a fresh bit, and continuously coring the Tertiary section. Hole 317 was terminated prematurely at a subbottom depth of 315 meters, above which three spot cores were obtained.

Hole $317 \mathrm{~A}$ began continuously coring at 554 meters in middle Maestrichtian sediment and terminated in basalt at 943 meters. Hole $317 \mathrm{~B}$ continuously cored the Quaternary through lower Eocene interval (0 to $424 \mathrm{~m})$, and was terminated prematurely when a fragment from a broken pump got into the drill string and prevented retrieval of the core barrel. The lower Eocene to middle Maestrichtian material between the cored intervals at $317 \mathrm{~B}$ and $317 \mathrm{~A}$ (424 to $554 \mathrm{~m}$ ) was not sampled.

Radiolarians are common and well preserved within only the upper Miocene through upper Oligocene section at this site (Cores 317B-7 through 317B-27; depth = 54-254 m). Poorly preserved and nondiagnostic radiolarian debris is present in the Quaternary and Pliocene intervals. Radiolarians are absent below the upper Oligocene sediments, except for some calcified and poorly preserved radiolarians in the Upper Cretaceous material of Cores $317 \mathrm{~A}-8$ through $317 \mathrm{~A}-11$ $(601-604 \mathrm{~m})$. These specimens were insufficiently preserved for reliable identification by optical microscopy.

The following radiolarian zonal boundaries can be identified in the Cenozoic material examined from Site 317 (see Table 2). The base of the Quaternary was identified by the extinction of discoasters, and lies between 16 and 25.5 meters (between 317B-2, CC and 317B-3, CC). The Pterocanium prismatium Zone and Spongaster pentas Zone were not sufficiently represented to be iden- tified. The base of the Stichocorys peregrina Zone lies between 77 and 78.5 meters (between 317B-9-3, 78-80 $\mathrm{cm}$ and $371 \mathrm{~B}-9-4,70-72 \mathrm{~cm}$ ). The base of the Ommatartus penultimus Zone lies between 89.5 and 91 meters (between 317B-10-5, 70-72 cm and 317B-10-6, 70-72 $\mathrm{cm})$. The base of the Ommatartus antepenultimus Zone lies between 107 and 108.5 meters (between 317B-12-4, $70-72 \mathrm{~cm}$ and $317 \mathrm{~B}-12-5,70-72 \mathrm{~cm})$. The base of the Cannartus petterssoni Zone lies between 130 and 139.5 meters (between 317B-14, CC and 317B-15, CC). The base of the Dorcadospyris alata Zone lies between 168 and 169 meters (between 317B-18, CC and 317B-19-1, $70-72 \mathrm{~cm}$ ). The base of the Calocycletta costata Zone lies between 173 and 174.5 meters (between 317B-19-4, 70$72 \mathrm{~cm}$ and $317 \mathrm{~B}-19-5,70-72 \mathrm{~cm}$ ). The base of the Calocycletta virginis Zone lies between 219 and 220.5 meters (between 317B-24-3, 70-74 cm and 317B-24-4, 82$86 \mathrm{~cm})$. The base of the Lychnocanoma elongata Zone lies between 234.5 and 237 meters (between 317B-25, CC and 317B-26-2, 60-64 cm). The Dorcadospyris ateuchus Zone extends below 257 meters (Sample 317B-28-3, 70$74 \mathrm{~cm}$ ), the deepest sample in which identifiable radiolarians were observed.

\section{Site 318}

Site 318 was cored intermittently between the sea floor and the deepest penetration at 745 meters, except for a portion of the middle Eocene section (596 to 653 $\mathrm{m})$ which was cored continuously. Radiolarians of sufficient abundance and preservation for age determination are present in only two intervals of the sedimentary column cored at this site. The upper Miocene through 
TABLE 3

Radiolarians in Hole 317B

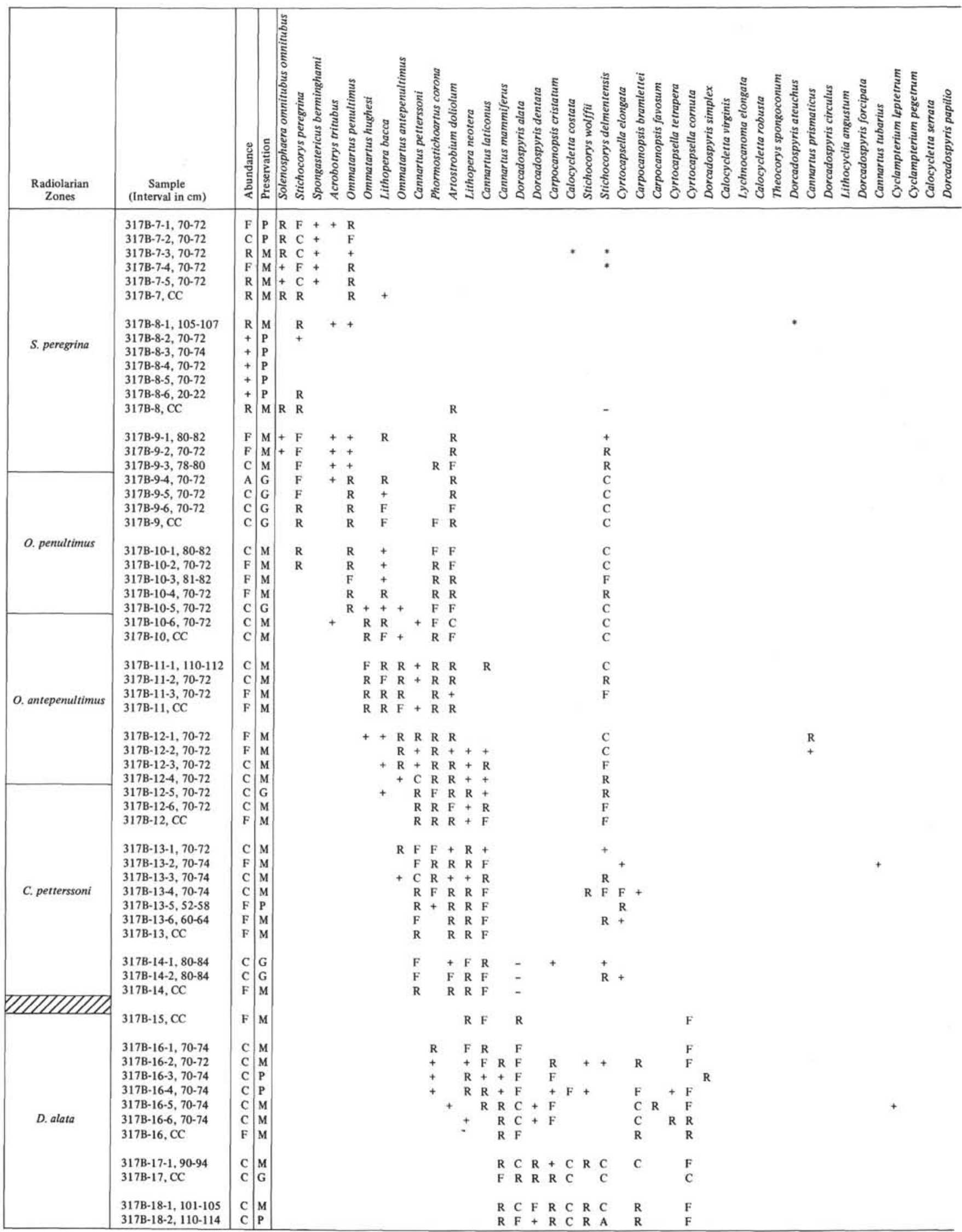


TABLE 3 - Continued

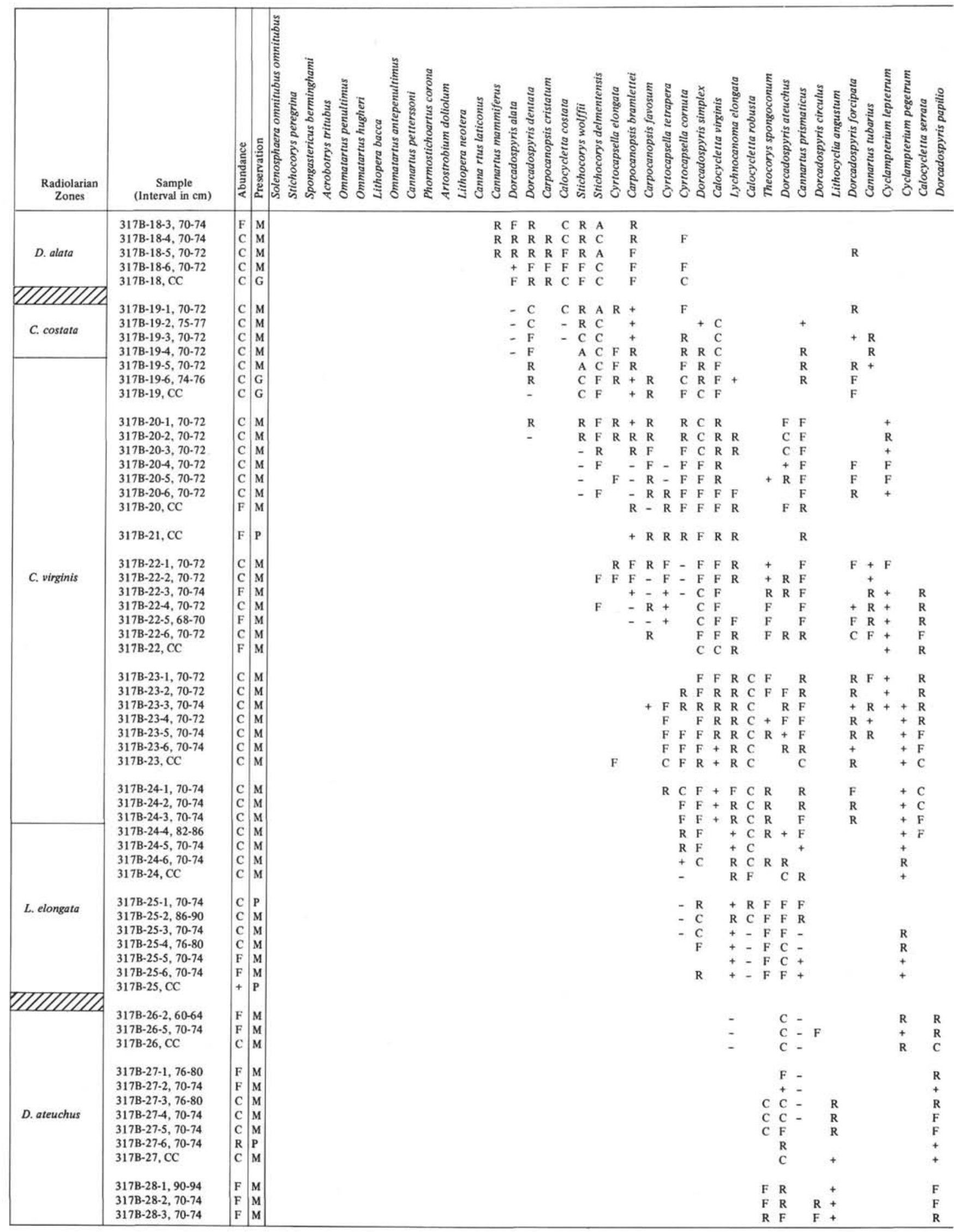


upper Oligocene (Cores 5 through 13; depth 131 to 359 $\mathrm{m})$ has a siliceous assemblage dominated by sponge spicules, but with a sufficient number of diagnostic radiolarians for reliable age control. The middle Eocene Thyrsocyrtis triacantha Zone is represented in a moderately to poorly preserved radiolarian assemblage in Cores 22 through 25 (depth 606 to $635 \mathrm{~m}$ ). The remainder of the cored intervals are barren of radiolarians.

Samples were prepared and examined from each section of the cored sediment. Because of the poor preservation of radiolarians in many of the cores, and because the radiolarian-bearing intervals were not cored continuously, the occurrences of radiolarians at Site 318 will be listed in the text, rather than in tabular form.

Core $1(0-7.5 \mathrm{~m})$ : A few moderately to poorly preserved radiolarians, mostly Eocene in age. Species observed include Thyrsocyrtis triacantha, Podocyrtis papalis, Theocampe amphora, Theocampe mongolfieri, Dorcadospyris triceros, and Thyrsocyrtis rhizodon. Actual age of deposition is late Neogene, based on calcareous microfossils, indicating substantial reworking.

Core $2(26.5-36 \mathrm{~m})$ : No radiolarians.

Core $3(64.5-74 \mathrm{~m})$ : A few radiolarian spines and fragments; no identifiable species.

Core 4(93-102.5 m): Abundant sponge spicules, a few radiolarian spines; no identifiable species.

Core $5(121.5-131 \mathrm{~m})$ : A few moderately to poorly preserved radiolarians. Neogene forms include Stichocorys peregrina and Siphocampe corbula. Admixed Eocene specimens of Lychnocanoma babylonis, Theocampe amphora, T. urceolus, and Podocyrtis papalis. Age of this core is upper Miocene ( $S$. peregrina Zone) or younger.

Core $6(150-157.5 \mathrm{~m})$ : A few well-preserved specimens of Stichocorys delmontensis, S. peregrina, Phormostichoartus corona, Artostrobium doliolum, Ommatartus penultimus, and Lithopera bacca. Age: Ommatartus penultimus Zone.

Core $7(178.5-188 \mathrm{~m})$ : A few moderately to poorly preserved specimens of $O$. hughesi, $S$. delmontensis, $A$. doliolum, L. bacca, and L. neotera. Age: Ommatartus antepenultimus Zone, based on the co-occurrence of the morphotypes of $L$. bacca and $L$. neotera.

Core $8(207-216.5 \mathrm{~m})$ : A few moderately preserved specimens of $S$. delmontensis, A. doliolum, Cannartus laticonus, and Calocycletta caepa. Abundant orosphaerids. Age: Cannartus petterssoni Zone, based on the absence of $O$. antepenultimus and $O$. hughesi.

Core $9(235.5-245 \mathrm{~m}):$ A diverse radiolarian assemblage, dominated by reworked Eocene material, with middle Miocene specimens of Cyrtocapsella japonica, Calocycletta costata, Cyrtocapsella tetrapera, and Stichocorys delmontensis. Age: Calocycletta costata Zone.

Core $10(264-273.5 \mathrm{~m})$ : A few moderately preserved specimens of Dorcadospyris simplex, Carpocanopsis bramlettei, Cyrtocapsella japonica, C. cornuta, and Theocorys spongoconum. Age: Calocycletta virginis Zone.

Core 11 (292.5-302 m): A few well-preserved specimens of $C$. virginis, C. serrata, Cyrtocapsella tetrapera, Dorcadospyris simplex, and D. ateuchus. Age: Calocycletta virginis Zone.
Core 12 (321-330.5 m): Rare specimens of Cannartus prismaticus, D. ateuchus, Calocycletta robusta, and D. papilio. Age: L. elongata Zone.

Core $13(349.5-359 \mathrm{~m})$ : Rare specimens of $D$. ateuchus, D. papilio, L. elongata, and Cyclampterium milowi. Age: Dorcadospyris ateuchus Zone.

Cores 14 through 21 are barren of radiolarians or contain only unidentifiable fragments.

Cores 22 through $25(596.5-634.5 \mathrm{~m})$ : A few wellpreserved specimens of Eocene radiolarians, including: Theocampe amphora, Phormocyrtis striata striata, Thyrsocyrtis triacantha, Eusyringium lagena, Theocampe mongolfieri, Calocyclas hispida, Lychnocanoma babylonis, Podocyrtis sinuosa, Theocotyle ficus, Thyrsocyrtis rhizodon, and Podocyrtis diamesa. Age: Thyrsocyrtis triacantha Zone. Radiolarians are absent below Core 25 .

The physiographic setting of this site is favorable for the accumulation of erosional products from the nearly Tuamotu Ridge; consequently, the extensive reworking of radiolarian debris within certain cored intervals is not surprising.

\section{DISCUSSION OF RESULTS}

\section{Preservation of Radiolarian Assemblages}

Three principal factors are responsible for low abundance or poor preservation of radiolarian assemblages: (1) low silica production in surface waters; (2) chemical dissolution at the benthonic boundary layer; and (3) post-depositional diagenesis leading to chert formation. Each of these mechanisms should be considered as a possible factor in the varying degree of preservation of radiolarians at the Leg 33 sites.

At the two equatorial sites ( 315 and 316 ), radiolarians are common and well preserved within all intervals cored between the Quaternary and upper Eocene; below this level radiolarians are absent, and chert horizons are interbedded with the calcareous material. This evidence suggests that biogenic silica deposition may have occurred through much of the sedimentary history at each of these two sites, but that chert formation has resulted from the remobilization of most of the silica of preOligocene age.

In the two sites from subtropical southern latitudes (317 and 318), radiolarians are common and well preserved within only the upper Oligocene through upper Miocene intervals of the cored material. Silica accumulation is not occurring in these latitudes today, and evidently did not occur prior to the late Oligocene. The Pacific plate underlying Sites 317 and 318 has migrated on the order of one or two degrees northward since the late Miocene, so that these sites were located in slightly higher southern latitudes during the times of increased silica production and accumulation. This small amount of northward plate motion is probably inadequate to explain the varying silica accumulation, because of the similarity in the silica accumulation record at these two widely separated sites. The most plausible explanation is a change in the physical oceanographic setting of the south-central Pacific during the late Oligocene to late Miocene, such that a zone of divergence and high productivity existed in subtropical latitudes $\left(10^{\circ}-15^{\circ} \mathrm{S}\right)$ during this time interval. 


\section{Unconformities}

The existence of unconformities at the Leg 33 sites can be reliably documented within only certain portions of the sites, since only a relatively few intervals were cored continuously. At Site 316 three significant unconformities were cored; these unconformities correspond approximately to the depth of prominent acoustic reflectors. These unconformities are of the following age: middle Miocene (Core 3, 267-276 m); lower Miocene/lower Oligocene (Core 4, 391-400 m); and lower Oligocene/middle Eocene (Core 5, 447-456 m). These unconformities may be indicative of episodic erosional events associated with turbidite deposition from the nearby Line Islands Ridge; alternatively they may be a result of episodic flow of Antarctic Bottom Water eastward through passages in the Line Islands Ridge.

\section{LIST OF SPECIES}

The purpose of this list is to provide bibliographic references to the taxa mentioned in this report. When the published literature contains several different concepts of the limits of a species, the reference cited conforms to the concept as applied here.

Acrobotrys tritubus Riedel, 1957, p. 80, pl. 1, fig. 5; Riedel and Sanfilippo, 1971, pl. 1J, fig. 19, 20.

Amphicraspedum murrayanum Haeckel, 1887, p. 523, pl. 44, fig. 10; Sanfilippo and Riedel, 1973, p. 524, pl. 10, fig. 3-6; pl. 28, fig. 1. Amphirhopalum ypsilon Haeckel, 1887, p. 522; Nigrini, 1967, p. 35, pl. 3 , fig. 3a-d.

Anthocyrtidium angulare Nigrini, 1971 , p. 445 , pl. 34.1 , fig. $3 \mathrm{a}, \mathrm{b}$.

Artophormis gracilis Riedel, 1959, p. 300, pl. 2, fig. 12, 13; Riedel and Sanfilippo, 1970, p. 532, pl. 13, fig. 6, 7.

Artostrobium doliolum Riedel and Sanfilippo, 1971, p. 1599, pl. 1H, fig. $1-3$; pl. 8, fig. 14, 15.

Axoprumum angelinum (Campbell and Clark), Kling, 1973, p. 634, pl. 1, fig. 13-16; pl. 6, fig. 14-18.

Bekomiforma mynx Sanfilippo and Riedel, 1974, p. 1020, pl. 2, fig. 3-5. Buccinosphaera invaginata Haeckel, 1887, p. 99, pl. 5, fig. 11; Nigrini, 1971, p. 445 , pl. 34.1 , fig. 2.

Calocyclas hispida (Ehrenberg); Foreman, 1973, p. 434, pl. 1, fig. 1215.

Calocyclas turris Ehrenberg; Foreman, 1973, p. 434.

Calocycletta caepa Moore, 1972, p. 150, pl. 2, fig. 4-7.

Calocycletta costata (Riedel), Riedel and Sanfilippo, 1970, p. 535, pl. 14, fig. 12; Moore, 1972, p. 147, pl. 1, fig. 8.

Calocycletta robusta Moore, 1971, p. 743, pl. 10, fig. 5, 6; 1972, pl. 48, pl. 1 , fig. 6.

Calocycletta serrata Moore, 1972, p. 148, pl. 2, fig. 1-3.

Calocycletta virginis (Haeckel), Riedel and Sanfilippo, 1970, p. 535, pl. 14, fig. 10; Moore, 1972, p. 147, pl. 1, fig. 7.

Calocycloma castum (Haeckel), Foreman, 1973, p. 434, pl. 1, fig. 7, 9, 10.

Cannartus bassanii (Carnevale), Sanfilippo et al., 1973, p. 216, pl. 1, fig. 1-3.

Cannartus laticonus Riedel, 1959, p. 291, pl. 1, fig. 5; Riedel and Sanfilippo, 1971, pl. 1C, fig. 13, 14.

Cannartus mammiferus (Haeckel), Riedel, 1959, p. 291, pl. 1, fig. 4.

Cannartus (?) petterssoni Riedel and Sanfilippo, 1970, p. 520, pl. 14, fig. $3 ; 1971$, pl. 1C, fig. 19, 20.

Cannartus prismaticus (Haeckel), Riedel and Sanfilippo, 1970, p. 520, pl. 15 , fig. $1 ; 1971$, p. 1588 , pl. 2C, fig. 11-13.

Cannartus tubarius (Haeckel), Riedel and Sanfilippo, 1970, p. 520, pl. 15, fig. 2; Kling, 1971, pl. 3, fig. 3.

Cannartus violina Haeckel, 1887, p. 358; Riedel, 1959, p. 290, pl. 1,fig. 3; Moore, 1971, pl. 12, fig. 4.

Carpocanopsis bramlettei Riedel and Sanfilippo, 1971, p. 1597, pl. 2G, fig. $8-14$; pl. 8, fig. 7.

Carpocanopsis cingulatum Riedel and Sanfilippo, 1971, p. 1597, pl. 2G, fig. $17-21$; pl. 8, fig. 8 .

Carpocanopsis cristatum (Carnevale) ?, Riedel and Sanfilippo, 1971, p. 1597, pl. 1G, fig. 16; pl. 2G, fig. 1-7.
Carpocanopsis favosum (Haeckel), Riedel and Sanfilippo, 1971, p. 1597, pl. 2G, fig. 15, 16; pl. 8, fig. 9-11.

Centrobotrys petrushevskayae Sanfilippo and Riedel, 1973, p. 532, pl. 36 , fig. $12,13$.

Clathrocorona atreta Sanfilippo and Riedel, Sanfilippo et al., 1973, p. 219, pl. 4, fig. 5-8.

Clathrocycloma capitaneum Foreman, 1973, p. 434, pl. 2, fig. 15; pl. 11, fig. 11.

Collosphaera sp. A, Knoll and Johnson, 1975, pl. 2, fig. 4-6.

Collosphaera tuberosa Haeckel, 1887, p. 97; Nigrini, 1971, p. 445, pl. 34.1 , fig. 1.

Cyclampterium (?) brachythorax Sanfilippo and Riedel, 1970, p. 457, pl. 2, fig. 15, 16; Riedel and Sanfilippo, 1971, pl. 1E, fig. 7.

Cyclampterium (?) leptetrum Sanfilippo and Riedel, 1970, p. 456, pl. 2, fig. 11, 12; Riedel and Sanfilippo, 1971, pl. 2D, fig. 9-12.

Cyclampterium (?) milowi Riedel and Sanfilippo, 1971, p. 1593, pl. 3B, fig. 3; pl. 7, fig. 8, 9; Sanfilippo et al., 1973, pl. 220, pl. 4, fig. 12-14.

Cyclampterium (?) pegetrum Sanfilippo and Riedel, 1970, p. 456, pl. 2, fig. 8-10; Riedel and Sanfilippo, 1971, pl. 2D, fig. 13, 14; pl. 3B, fig. $1,2$.

Cyclampterium (?) tanythorax Sanfilippo and Riedel, 1970, p. 457, pl. 2, fig. 13, 14; Riedel and Sanfilippo, 1971, pl. 1E, fig. 8-10; pl. 2D, fig. 7,8 .

Cyrtocapsella cornuta Haeckel, Sanfilippo and Riedel, 1970, p. 453, pl. 1, fig. 19, 20; Sanfilippo et al., 1973, pl. 5, fig. 1, 2.

Cyrtocapsella elongata (Nakaseko), Sanfilippo and Riedel, 1970, p. 452 , pl. I, fig. 11, 12.

Cyrtocapsella japonica (Nakaseko), Sanfilippo and Riedel, 1970, p. 452, pl. 1, fig. 13-15; Sanfilippo et al., 1973, pl. 5, fig. 3.

Cyrtocapsella tetrapera Haeckel; Sanfilippo and Riedel, 1970, p. 453, pl. 1, fig. 16-18; Sanfilippo et al., 1973, pl. 5, fig. 4-6.

Dendrospyris bursa Sanfilippo and Riedel, Sanfilippo et al., 1973, p. 217, pl. 2, fig. 9-13.

Dendrospyris fragoides Sanfilippo and Riedel, 1973, p. 526, pl. 15, fig. 8-13; pl. 31, fig. 13, 14.

Dictyocoryne ontongensis Riedel and Sanfilippo, 1971, p. 1588, pl. 1E, fig. 1, 2; pl. 4, fig. 9-11.

Dictyospyris gigas Ehrenberg, Sanfilippo and Riedel, 1973, p. 527, pl. 16 , fig. 9 , 10; pl. 32 , fig. $10,11$.

Dorcadospyris alata (Riedel), Riedel and Sanfilippo, 1970, pl. 14, fig. 5; 1971, pl. 2D, fig. 1; Moore, 1971, pl. 11, fig. 3, 4.

Dorcadospyris ateuchus (Ehrenberg), Riedel and Sanfilippo, 1970, pl. 15, fig. 4; 1971, p. 1590, pl. 2D, fig. 6, pl. 3A, fig. 9, 10.

Dorcadospyris circulus (Haeckel), Moore, 1971, p. 739, pl. 8, fig. 3-5.

Dorcadospyris confluens (Ehrenberg), Goll, 1969, p. 337; Sanfilippo and Riedel, 1973 , p. 528 , pl. 17 , fig. $6-10$; pl. 33, fig. 1.

Dorcadospyris dentata (Haeckel), 1887, p. 1037; Riedel, 1957, p. 79, pl. 1, fig. 3.

Dorcadospyris forcipata (Haeckel), Moore, 1971, p. 740, pl. 10, fig. 1, 2.

Dorcadospyris papilio (Riedel), Riedel and Sanfilippo, 1970, p. 523, pl. 15, fig. 5; Moore, 1971, p. 739, pl. 8, fig. 6, 7.

Dorcadospyris quadripes Moore, 1971, p. 738, pl. 7, fig. 3-5.

Dorcadospyris simplex (Riedel); Riedel and Sanfilippo, 1970, pl. 15, fig. 6 .

Dorcadospyris spinosa Moore, 1971, p. 739, pl. 7, fig. 1, 2.

Dorcadospyris triceros (Ehrenberg); Moore, 1971, p. 739, pl. 6, fig. 1-3. Eucyrtidium cienkowskii Haeckel, 1887, p. 1493; Sanfilippo et al., 1973 , p. 221 , pl. 5, fig. 7-11.

Eusyringium fistuligerum (Ehrenberg), Riedel, 1957, p. 94, pl. 4, fig. 8; Riedel and Sanfilippo, 1970, p. 527, pl. 8, fig. 8, 9; Foreman, 1973, p. 435 , pl. 11 , fig. 6 .

Eusyringium lagena (Ehrenberg) (?); Riedel and Sanfilippo, 1970, p. 527, pl. 8, fig. 5-7; Foreman, 1973, p. 435 , pl. 11, fig. 4, 5 .

Lithapium mitra (Ehrenberg), Riedel and Sanfilippo, 1970, p. 520, pl. 4 , fig. 6,7 .

Lithocyclia angustum (Riedel), Riedel and Sanfilippo, 1970, p. 522, pl. 13, fig. 1, 2; 1971, pl. 3A, fig. 1, 3.

Lithocyclia aristotelis (Ehrenberg) group, Riedel and Sanfilippo, 1970, p. $522 ; 1971$, pl. 3 A, fig. 4,5 .

Lithocyclia crux Moore, 1971, p. 737, pl. 6, fig. 4.

Lithomitra docilis Foreman, 1973, p. 431, pl. 8, fig. 20-22; pl. 9, fig. 3-5.

Lithopera bacca Ehrenberg, 1872, p. 314; Nigrini, 1967, p. 54, pl. 6, fig. 2; Sanfilippo and Riedel, 1970, p. 455, pl. 1, fig. 29.

Lithopera baueri Sanfilippo and Riedel, 1970, p. 455, pl. 2, fig. 1, 2.

Lithopera neotera Sanfilippo and Riedel, 1970, p. 454, pl. 1, fig. 24-26, 28 . 
Lithopera renzae Sanfilippo and Riedel, 1970, p. 454, pl. 1, fig. 21-23, 27.

Lithopera thornburgi Sanfilippo and Riedel, 1970, p. 455, pl. 2, fig. 4-6.

Lophophaena (?) capito Ehrenberg group, Petrushevskaya and Kozlova, 1972, p. 535, pl. 33, fig. 20-23.

Lychnocanoma babylonis (Clark and Campbell) group, Foreman, 1973 , p. 437 , pl. 2 , fig. 1.

Lychnocanoma elongata (Vinassa), Sanfilippo et al., 1973, p. 221, pl. 5, fig. 19, 20.

Ommatartus antepenultimus Riedel and Sanfilippo, 1970, p. 521, pl. 14; 1971, pl. 1C, fig. 11, 12.

Ommatartus avitus (Riedel), Riedel and Sanfilippo, 1971, p. 1588, pl. 4, fig. 6.

Ommatartus hughesi (Campbell and Clark), Riedel and Sanfilippo, 1970 , p. 521 ; 1971 , pl. 1C, fig. $17,18$.

Ommatartus penultimus (Riedel), Riedel and Sanfilippo, 1970, p. 521; 1971, pl. 1C, fig. 8-10.

Ommatartus tetrathalamus (Haeckel), Riedel and Sanfilippo, 1971, p. 1588 , pl. 1C, fig. 5-7.

Phormocyrtis striata striata Brandt, Foreman, 1973, p. 438, pl. 7, fig. 5, $6,9$.

Phormostichoartus corona (Haeckel), Riedel and Sanfilippo, 1971, p. 1600 , pl. 11, fig. 12 ; pl. 21 , fig. 17 ; pl. $3 \mathrm{E}$, fig. 15-19.

Podocyrtis (Lampterium) chalara Riedel and Sanfilippo, 1970, p. 535, pl. 12, fig. 2, 3 .

Podocyrtis (Lampterium) goetheana (Haeckel), Riedel and Sanfilippo, 1970 , p. $535 ; 1971$, pl. 8 , fig. 13.

Podocyrtis (Lampterium) mitra (Ehrenberg), Riedel and Sanfilippo, 1970 , p. 534 , pl. 11 , fig. 5,6 .

Podocyrtis (Lampterium) sinuosa Ehrenberg (?), Riedel and Sanfilippo, 1970, pl. 11, fig. 3, 4.

Podocyrtis (Podocyrtis) ampla Ehrenberg, Riedel and Sanfilippo, 1970, p. 533 , pl. 12 , fig. 7,8 .

Podocyrtis (Podocyrtis) diamesa Riedel and Sanfilippo, 1970, p. 53, pl. 12, fig. 4; Sanfilippo and Riedel, 1973, p. 531, pl. 20, fig. 9, 10; pl. 35 , fig. 10,11 .

Podocyrtis papalis Ehrenberg, 1847, fig. 2; 1874, p. 251; Riedel and Sanfilippo, 1970, p. 533, pl. 11, fig. 1; Sanfilippo and Riedel, 1973, pl. 20, fig. 11-14; pl. 36, fig. 2,3 .

Podocyrtis (Podocyrtis) phyxis Sanfilippo and Riedel, 1973, p. 531; Riedel and Sanfilippo, 1970, pl. 12, fig. 6.

Pterocanium praetextum (Ehrenberg), Riedel, 1957, p. 86, pl. 3, fig. 13; Moore, 1971, pl. 13, fig. 3.

Pterocanium prismatium Riedel, 1957, p. 87, pl. 3, fig. 4, 5; Riedel and Sanfilippo, 1971, pl. 8, fig. 1.

Pterocorys hertwigii (Haeckel), Sanfilippo and Riedel, 1974, pl. 3, fig. 12-14.

Rhopalocanium ornatum Ehrenberg, 1847, fig. 3; 1854, pl. 36, fig. 9; 1874 , p. 256 ; 1876, p. 82, pl. 17, fig. 8; Foreman, 1973, p. 439, pl. 2, fig. 8-10; pl. 12 , fig. 3 .

Siphocampe corbula (Harting), Riedel and Sanfilippo, 1971, p. 1601, pl. $1 \mathrm{H}$, fig. $18-25$.

Solenosphaera omnitubus omnitubus Riedel and Sanfilippo, 1971; p. 1586, pl. 1A, fig. 24; pl. 4, fig. 1, 2; Sanfilippo and Riedel, 1974, p. 1024 , pl. 1, fig. 1 .

Solenosphaera omnitubus procera Sanfilippo and Riedel, 1974, p. 1024, pl. 1, fig. 2-5.

Spongaster klingi Riedel and Sanfilippo, 1971, p. 1589, pl. 4, fig. 7, 8.

Remarks: Sanfilippo and Riedel (1973, p. 524) state that Spongaster

klingi Riedel and Sanfilippo is probably a junior synonym of Spongastericus berminghami Campbell and Clark (1944).

Spongaster pentas Riedel and Sanfilippo, 1970, p. 523, pl. 15, fig. 3.

Spongaster tetras Ehrenberg, 1860, p. 833; Nigrini, 1967, p. 41, pl. 5, fig. $1 \mathrm{a}-\mathrm{b}, 2$.

Stichocorys armata (Haeckel), Riedel and Sanfilippo, 1971, p. 1595, pl. 2E, fig. 13-15; Sanfilippo et al., 1973, p. 222, pl. 6, fig. 1, 2.

Stichocorys delmontensis (Campbell and Clark), Sanfilippo and Riedel, 1970, p. 451, pl. 1, fig. 9; Riedel and Sanfilippo, 1971, pl. $1 \mathrm{~F}$, fig. $5-7$; pl. $2 \mathrm{E}$, fig. $10,11$.

Stichocorys peregrina (Riedel), Riedel and Sanfilippo, 1970, p. 530; 1971 , pl. 8, fig. 5 .

Stichocorys wolffii Haeckel, 1887, p. 1479; Riedel, 1954, p. 173, pl. 1, fig. 4; Riedel, 1957, p. 92, pl. 4, fig. 6, 7; Riedel and Sanfilippo, 1971, pl. 2E, fig. 8, 9.

Theocampe amphora (Haeckel) group, Foreman, 1973, p. 431, pl. 8, fig. 7, 9-13; pl. 9, fig. 8, 9 .
Theocampe armadillo (Ehrenberg) group, Riedel and Sanfilippo, 1971, p. 1601, pl. 3E, fig. 3-6.

Theocampe mongolfieri (Ehrenberg), Burma, 1959, p. 239; Riedel and Sanfilippo, 1970, p. 536, pl. 12, fig. 9; Foreman, 1973, p. 432, pl. 8, fig. 1; pl. 9, fig. 17.

Theocampe pirum (Ehrenberg), Riedel and Sanfilippo, 1971, p. 1601, pl. 3E, fig. 10, 11; Foreman, 1973, pl. 9, fig. 11, 12.

Theocampe urceolus (Haeckel), Foreman, 1973, p. 432, pl. 8, fig. 14-17; pl. 9, fig. 6, 7.

Theocorys anaclasta Riedel and Sanfilippo, 1970, p. 530, pl. 10, fig. 2, 3; Sanfilippo and Riedel, 1973, p. 440, pl. 5, fig. 14, 15.

Theocorys spongoconum Kling, 1971, p. 1087, pl. 5, fig. 6; Riedel and Sanfilippo, 1971, pl. 2F, fig. 4; pl. 3C, fig. 3.

Theocorythium trachelium (Ehrenberg), Nigrini, 1967, p. 79, pl. 8, fig. 2.

Theocotyle (Theocotylissa) ficus (Ehrenberg), Foreman, 1973, p. 441, pl. 4 , fig. 16-20.

Theocyrtis annosa (Riedel), Riedel and Sanfilippo, 1970, p. 535, pl. 15, fig. 9.

Theocyrtis tuberosa Riedel, 1959, p. 258, pl. 2, fig. 10, 11; Moore, 1971, p. 743 , pl. 5 , fig. 5,6 .

Thyrsocyrtis bromia Ehrenberg, 1874, p. 260; 1876, p. 84, pl. 12, fig. 2; Riedel and Sanfilippo, 1970, p. 526; 1971, pl. 8, fig. 6; Moore 1971, pl. 5, fig. 1-3.

Thyrsocyrtis hirsuta tensa Foreman, 1973, p. 442, pl. 3, fig. 13-16; pl. 12 , fig. 8.

Thyrosocyrtis rhizodon Ehrenberg, 1874, p. 262; 1876, p. 94, pl. 12, fig. 1; Riedel and Sanfilippo, 1970, p. 525, pl. 7, fig. 6, 7; Foreman, 1973, p. 442 , pl. 3 , fig. $1,2$.

Thyrsocyrtis tetracantha (Ehrenberg), Riedel and Sanfilippo, 1970, p. 527; Moore, 1971, pl. 4, fig. 3.

Thyrsocyrtis triacantha (Ehrenberg), Riedel and Sanfilippo, 1970, p. 526, pl. 8, fig. 2, 3; Foreman, 1973, p. 442, pl. 12, fig. 9-11.

\section{ACKNOWLEDGMENTS}

I thank H.C. Meyer for assistance in slide preparation and C. Rowell for identifying some of the taxa in samples from Hole 317B. This work received partial support under NSF Grant GA-36825.

\section{REFERENCES}

Berggren, W.A., 1972. A Cenozoic time scale-some implications for regional geology and paleobiogeography: Lethaia, v. 5, p. 195-215.

Burma, B.H., 1959. On the status of Theocampe Haeckel, and certain similar genera: Micropaleontology, v. 5, p. 325330.

Campbell, A.S. and Clark, B.L., 1944. Miocene radiolarian faunas from southern California: Geol. Soc. Am. Spec. Paper 51, p. 1-76.

Dinkelman, M.G., 1973. Radiolarian stratigraphy: Leg 16, Deep Sea Drilling Project. In van Andel, T.H., Heath, G.R., et al., Initial Reports of the Deep Sea Drilling Project, Volume 16: Washington (U.S. Government Printing Office), p. 747-813.

Ehrenberg, C.G., 1847. Über die mikroskopischen kieselschaligen Polycystinen als mächtige Gebirgsmasse von Barbados und über das Verhältnes der aus mehr als 300 neuen Arten bestehenden gang eigenthümlichen Formengruppe jener Felsmasse zu den lebenden Thieren und zur Kreidebildung. Eine neue Anregung zur Erforschung des Erdlebens: Mber. Preuss. Akad. Wiss. Berlin Jahrg. 1847, p. 40-60.

1854. Mikrogeologie: Leipzig (Voss).

1860. Über den Tiefgrund des stillen Oceans zwischen Californien und den Sandwich-Inseln aus bis $15,600^{\prime}$ Tiefe nach Lieut. Brooke: Mber. Preuss. Akad. Wiss. Berlin, Jahrg. 1860, p. 819-833. 
1874. Grössere Felsproben des PolycystinenMergels von Barbados mit weiteren Erläuterungen: Mber. Preuss. Akad. Wiss. Berlin, Jahrg. 1873, p. 213-263.

1876. Forsetzung der mikrogeologischen Studien als Gesammt-Ubersicht der mikroskopischen Paläontologie gleichartig analysirter Gebirgsarten der Erde, mit specieller Rücksicht auf den Polycystinen-Merger von Barbados: Abh. Preuss. Akad. Wiss. Berlin, Jahrg. 1875, p. 1226.

Foreman, H.P., 1973a. Radiolaria of Leg 10 with systematics and ranges for the families Amphypyndacidae, Artostrobiidae, and Theoperidae. In Worzel, J.L., Bryant, W., et al., Initia: Reports of the Deep Sea Drilling Project, Volume 10: Washington (U.S. Government Printing Office), p. 407-474.

1973b. Radiolaria from DSDP Leg 20. In Heezen, B.C., MacGregor, I.D., et al., Initial Reports of the Deep Sea Drilling Project, Volume 20: Washington (U.S. Government Printing Office), p. 249-305.

Goll, R.M., 1969. Classification and phylogeny of Cenozoic Trissocyclidae (Radiolaria) in the Pacific and Caribbean basins, Part II: J. Paleontol., v. 43, p. 322-339.

Haeckel, E., 1887. Report on the Radiolaria collected by H.M.S. Challenger during the years 1873-76: Rept. Voyage Challenger, Zool., v. 18.

Kling, S., 1971. Radiolaria: Leg 6 of the Deep Sea Drilling Project. In Fischer, A.G., Heezen, B.C., et al., Initial Reports of the Deep Sea Drilling Project, Volume 6: Washington (U.S. Government Printing Office), p. 1069-1117.

1973. Radiolaria from the eastern North Pacific, Deep Sea Drilling Project, Leg 18. In Kulm, L.D., Von Huene, R., et al., Initial Reports of the Deep Sea Drilling Project, Volume 18: Washington (U.S. Government Printing Office), p. 617-671.

Knoll, A.H. and Johnson, D.A., 1975. Late Pleistocene evolution of the collosphaerid Buccinosphaera invaginata Haeckel: Micropaleontology, v. 21.

Moore, T.C., 1971. Radiolaria. In Tracey, J.I., Jr., Sutton, G.H., et al., Initial Reports of the Deep Sea Drilling Project, Volume 8: Washington (U.S. Government Printing Office), p. 727-775.

1972. Mid-Tertiary evolution of the radiolarian genus Calocycletta: Micropaleontology, v. 18, p. 244-252. 1973. Radiolaria from Leg 17 of the Deep Sea Drilling Project. In Winterer, E.L., Ewing, J.I., et al., Initial Reports of the Deep Sea Drilling Project, Volume 17: Washington (U.S. Government Printing Office), p. 797-869.

Nigrini, C.A., 1967. Radiolaria in pelagic sediments from the Indian and Atlantic oceans: Scripps Inst. Oceanogr. Bull., v. 11 , p. 1-106.
1971. Radiolarian zones in the Quaternary of the equatorial Pacific Ocean. In Funnell, B.M. and Riedel, W.R. (Eds.); The micropaleontology of oceans: (Cambridge University Press), p. 443-461.

Petrushevskaya, M.G. and Kozlova, G.E., 1972. Radiolaria: Leg 14, Deep Sea Drilling Project. In Hayes, D.E., Pimm, A.C., et al., Initial Reports of the Deep Sea Drilling Projec, Volume 14: Washington (U.S. Government Printing Office), p. 495-648.

Riedel, W.R., 1954. The age of the sediment collected at Challenger Station 225, and the distribution of Ethmodiscus rex: Deep-Sea Res., v. 1, p. 170-175.

, 1957. Radiolaria: a preliminary stratigraphy: Rept. Swed. Deep-Sea Exped., v. 6, p. 61-96.

1959. Oligocene and lower Miocene Radiolaria in tropical Pacific sediments: Micropaleontology, v. 5, p. 285302.

Riedel, W.R. and Sanfilippo, A., 1970. Radiolaria, Leg 4, Deep Sea Drilling Project. In Bader, R.G., Gerard, R.D., et al., Initial Reports of the Deep Sea Drilling Project, Volume 4: Washington (U.S. Government Printing Office), p. 503-575.

1971. Cenozoic Radiolaria from the western tropical'Pacific, Leg 7. In Winterer, E.L., Riedel, W.R., et al., Initial Reports of the Deep Sea Drilling Project, Volume 7: Washington (U.S. Government Printing Office), p. 1529-1672.

1974. Radiolaria from the southern Indian Ocean, DSDP, Leg 26. In Davies, T.A., Luyendyk, B.P., et al., Initial Reports of the Deep Sea Drilling Project, Volume 26: Washington (U.S. Government Printing Office), p. 771-813.

in press. Cenozic Radiolaria. In Ramsay, A.T.S. (Ed.), Oceanic Micropaleontology.

Sanfilippo, A., Burckle, L.H., Martini, E., and Riedel, W.R., 1973. Radiolarians, diatoms, silicoflagellates and calcareous nannofossils in the Mediterranean Neogene: Micropaleontology, v. 19, p. 205-234.

Sanfilippo, A. and Riedel, W.R., 1970. Post-Eocene 'closed' theoperid radiolarians: Micropaleontology, v. 16, p. 446462.

1973. Cenozoic Radiolaria (exclusive of theoperids, artostrobiids and amphypyndacids) from the Gulf of Mexico, Deep Sea Drilling Project, Leg 10. In Worzel, J.L., Bryant, W., et al., Initial Reports of the Deep Sea Drilling Project, Volume 10: Washington (U.S. Government Printing Office), p. 475-611.

1974. Radiolaria from the west central Indian Ocean and Arabian Sea, DSDP Leg 24. In Fisher, R.L., Bunce, E.T., et al., Initial Reports of the Deep Sea Drilling Project, Volume 24: Washington (U.S. Government Printing Office), p. 997-1035. 